\title{
Design and Fabrication of a Domestic Incinerator
}

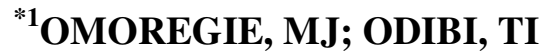 \\ Department of Production Engineering, Faculty of Engineering, University of Benin, \\ P.M.B 1154, Benin City, Nigeria \\ Email: monday.omoregie@uniben.edu andtina.odibi@uniben.edu
}

\begin{abstract}
A domestic incinerator which can be used to dispose waste was designed, successfully constructed and tested. A simple scrubber was devised and coupled to the equipment for the removal of waste gases and harmful dust emissions. Firing was achieved with waste oil which can be obtained from local automobile workshops and service stations. Thus the incineratorserves the purpose of dealing with household wastes as well as liquid wastes generated by the increasing number of automobile workshops in our local environment. Although the body of the system experienced a little of heat loss, the result showed that the system is preferable to open air burning and the incinerator performed with an efficiency of $72.1 \%$.It could be very useful for domestic application in urban and rural settlements, especially in our homes where paper and other nontoxic solid wastes are generated. () JASEM

https://dx.doi.org/10.4314/jasem.v21i5.27
\end{abstract}

Keywords: Incinerator, wastes, combustion, scrubber, lagging, conductivity

The waste management board of Nigeria has indeed come a long way in terms of carrying out different projects centred on waste management. The history and development of incinerators dates back to the end of the eighteenth century when demand for a better and cheaper means of waste material disposal began (Kassenberg and Sutter, 2006). Today, wastes generated by man pose grave danger to humans and the environment in our everyday life. It is therefore imperative to find adequate means of dealing with the problem especially at the domestic level. In many developing countries, uncontrolled dumping is often used for the disposal of solid waste. These dumps are frequently allowed to burn, either deliberately, as a means of volume reduction, or accidently by scavengers (Taylor, 2004).

Studies on waste composition in some Nigerian cities indicate that about $25 \%$ of most urban wastes in Nigeria comprises of paper and nontoxic materials, which can be combusted in suitably designed incinerators. Presently, these waste materials are either burnt uncontrollably to reduced volume or disposed of in landfills with adverse ecological implications (Cheremisinoff, 1990).

Incineration is an environmentally and technically superior method of waste disposal offering: Reliability, Safety and Efficiency. Other methods of waste disposal include:Ocean dumping, Sanitary landfill, Open dumping and Recycling.

In previous decades, landfills were primarily used for waste disposal, allowing nature to take its cause. Incineration thermally decomposes matter through oxidation, thereby reducing and minimizing the wastes and destroying their toxicity. It can be applied to industrial, municipal and hazardous wastes provided that they contain organic materials. After incineration, wastes are converted to Carbon monoxide $(\mathrm{CO})$, Carbon dioxide $\left(\mathrm{CO}_{2}\right)$, water $\left(\mathrm{H}_{2} \mathrm{O}\right)$ and Ash(Hogg, 2009).
Depending on the composition of the initial waste, compounds containing halogens, metals, nitrogen and sulphur may be produced. These compounds along with $\mathrm{CO}$ are deleterious to the atmosphere and highly regulated (Hogg, 2009)). To avoid the effects of these, we need to equip the incinerators with after burners, scrubbers, filtration units and membranes.

\section{MATERIALS AND METHODS}

Design Consideration: Estimates of waste generated in addition to the constituents of domestic wastes were obtained. A range of existing incinerators wereexamined and suitable type duly modified and recommended. Waste oil littering our various workshops was harnesses and used as fuel. The incinerator is a box-like structure which can withstand high temperatures. The innovation in this research is bubblingof waste gas from the incinerator through water with the purpose of reducing the harmful effects of the waste gas and dust.

The following factors were considered in the design and fabrication of the incinerator:

Types of Waste to be considered: Our design isbased on domestic solid and liquid wastes which are generated in homes. These include plants, old clothes, shoes, paper, packaging items, used vegetable oil etc. In this work we have considered the solid domestic wastes which can be burnt at a specific temperature up to $200^{\circ} \mathrm{C}$.

Volume of Waste to be burnt: The volume of waste burnt was derived from a survey carried out in the local community within Ugbowo and Uselu areas in Benin City, Edo state.A total of fifty (50) houses were visited in order to compute wastes generated as basis for sizing the incinerator.

Lagging material: Locally available clay was used as refractory material which contains particles of complex alumina-silicates (Ibhadode, 2001).Additional advantage is that the cost of purchase is low. 
Type of Fuel for burning: Our design made use of waste oilswhich are readily available at a low cost from automobile mechanic workshops. Firing with waste oil also helps to clean up the environment since these oils that were hitherto thrown into drains and adjourning lands now find useful application in the overall benefit of the community. Based on our calculation and design we used $49.5 \times 10^{6} \mathrm{~mm}^{3}$ of waste oil.

Mild steel was selected for the fabrication of the frame. The material belongs to the group of low carbon steels which are relatively cheap and possesses good formability and weldability properties (Ibhadode, 2001). It is also readily available.

Combustion Process: Waste material is burnt in the combustion chamber using a proportionate air/fuel mixture (Santoteri, 1985). This is illustrated schematically in Fig 1.

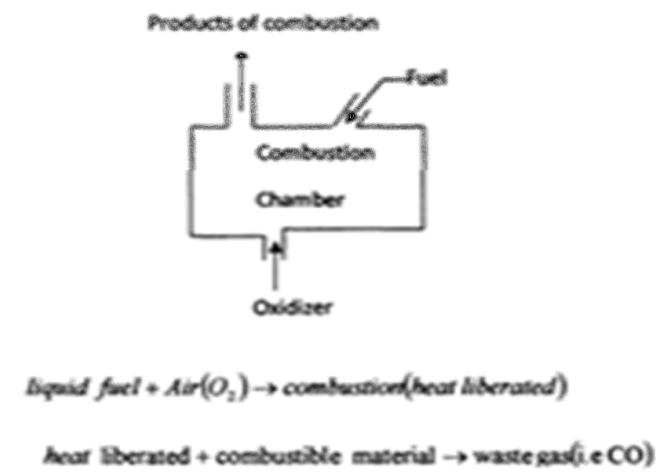

Fig 1: Combustion Chamber

Construction and Assembly: The different parts of the incinerator were fabricated according to design specifications and assembled together mainly by welding. Detailed Engineering drawing is shown in appendix 1 .

Heat Generated: To determine the amount of heat generated by the combustible waste, several trials were made to ascertain the approximate firing rate of the waste by closing the door of the combustion chamber to avoid heat loss (Lienhard, 2005). The combustion chamber was lagged to prevent heat loss. On the average, it took 12 minutes to completely burn6kg of waste using waste oil as fuel. Firing rate is obtained from the relationship:

$\mathrm{R}=\frac{\text { mass } \text { of waste }(\mathrm{kg})}{\text { time }(\mathrm{s})} \ldots 1$

Where $\mathrm{R}=$ firing rate

Also: $q=R C_{f} \ldots . .2$

Where: $\mathrm{q}=$ heat power $(\mathrm{KW}) ; \mathrm{C}_{\mathrm{f}}=$ calorific value $(\mathrm{J} / \mathrm{kg})=15 \times 10^{6} \mathrm{~J} / \mathrm{kg}$ (Lienhard, 2005); $\mathrm{Q}=$ heat transfer or heat generated $=$ Aq, Surface area (A) of the combustion chamber

$A=2(I b+l t+b t) \ldots .3$

Where: $l=$ length of chamber $=350 \mathrm{~mm}, \mathrm{~b}=$ breadth of camber $=520 \mathrm{~mm}$, and $\mathrm{t}=$ thickness of chamber $=$ $3 \mathrm{~mm}$

$Q=q A \ldots .4$

Design of Scrubber Unit: A 200 litre capacity galvanised sheet drum was used as container for the gas scrubbing water. The waste gas is bubbled through the water to scrub off the harmful dust and aspect of the waste gas. The heat transfer through the gas to the metal (pipe) is by convection. From Fourier heat transfer equation for convection heat transfer (Rajput, 2004):

$\hat{Q}=h A\left(t_{s}-t_{f}\right)$ 5

Where: $\hat{Q}=$ rate of heat transfer,h $=$ heat transfer coefficient, $A=$ surface area of pipe; $t_{f}=$ temperature of fluid (i.e. waste gas), $t_{s}=$ temperature of the solid (i.e. the pipe)

$$
\begin{aligned}
& R_{f}=\frac{1}{h A} \\
& \hat{Q}=\frac{t_{s}-t_{f}}{R_{f}}
\end{aligned}
$$

The thermal resistance of pipe and that of the fluid (i.e. gas) made up the total thermal resistance (Rajput, 2004). $R_{\mathrm{s}}=$ thermal resistance of the pipe is given by:

$$
R_{s}=\frac{\operatorname{In} \frac{r_{2}}{r_{1}}}{2 \pi L k} \ldots \ldots \ldots \ldots \ldots . . .8
$$

$\mathrm{L}=$ length of the pipe, $\mathrm{K}=$ thermal conductivity of pipe, $r_{1}=$ internal radius of the pipe, $r_{2}=$ external radius of the pipe; $R_{f}=$ thermal resistance of the fluid is given by:

$$
R_{f}=\frac{1}{h A}=\frac{1}{2 \pi r_{1} h}
$$

Total thermal resistance: $\mathrm{R}_{\mathrm{T}}=\mathrm{R}_{\mathrm{s}}+\mathrm{R}_{\mathrm{f}} \ldots \ldots \ldots \ldots 10$

$$
R_{T}=\frac{\operatorname{In} \frac{r_{2}}{r_{1}}}{2 \pi L k_{1}}+\frac{1}{2 \pi r_{1} h} \ldots \ldots \ldots \ldots \ldots . . .11
$$

Using the following parameters: $\mathrm{x}=$ thickness of pipe $=3 \mathrm{~mm} 0.003 \mathrm{~m}$ (Santoteri, 1985), $\mathrm{t}_{\mathrm{f}}=$ temperature of fluid (i.e. waste gas) $=200^{\circ} \mathrm{C}=473 \mathrm{~K}$; $\mathrm{t}_{\mathrm{s}}=$ temperature of the solid (i.e. the pipe); $\mathrm{h}=$ heat transfer coefficient of waste gas ranges from 5$35 \mathrm{~W} / \mathrm{m}^{2}$ at atmospheric pressure inside and outside tubes. (Rajput, 2004). Let $\mathrm{h}=5 \mathrm{~W} / \mathrm{m}^{2} \mathrm{k}$ (i.e. using the minimum value) (Santoteri, 1985); $\hat{Q}=$ heat transfer rate $=55350 \mathrm{~J} / \mathrm{s}$ 
$\mathrm{A}=$ cross sectional area of pipe, given by:

$A=\frac{\pi\left(d_{0}^{2}-d_{1}^{2}\right)}{4}$

Where: $\mathrm{d}_{\mathrm{o}}=$ external diameter of pipe, $\mathrm{d}_{0}=58 \mathrm{~mm}=$ $0.058 \mathrm{~m} ; \mathrm{d}_{1}=$ internal diameter of pipe, $\mathrm{d}_{1}=52 \mathrm{~mm}=$ $0.052 \mathrm{~m}$

The pipe is made from steel material, therefore, its thermal conductivity $\mathrm{K}=36.351 \mathrm{~W} / \mathrm{mK}$ (Rajput, 2004); Assuming the length of pipe to be: $\mathrm{L}=400 \mathrm{~mm}$ $=0.4 \mathrm{~m}$. The flow of the waste gas through the pipe is assumed to be laminar and steady thus: Reynolds number of the gas is less than 2000 (ie $\operatorname{Re}<2000$ ).

$R_{e}=\frac{p V D}{\mu}$ (Rajput, 2004)

Where: $\mathrm{p}=$ density of the waste gas $(\mathrm{CO}), \mathrm{V}=$ velocity of flow of the waste gas, $\mathrm{D}=$ diameter, $\mu=$

dynamic viscosity, $R_{e}=$ Reynolds number of gas

Thickness of Insulation: To reduced heat losses from the burning waste, the combustion chamber was properly insulated with clay of $70 \mathrm{~mm}$ thickness. The insulating material used in this work is clay this is because of its low cost and ready availability. The thermal conductivity of clay is $0.25 \mathrm{~W} / \mathrm{mK}$ (Lienhard, 2005). The average temperature (final temperature) of the combustion chamber depends on the combustible materials. Applying Fourier's heat transfer (Rajput, 2004)by conduction we have:

$\hat{Q}=k A \frac{d T}{d x}$ . .14

Where; $d T=T_{2}-T_{1}$

$d x \rightarrow x$
$q=\frac{k A\left(T_{2}-T_{1}\right)}{x}=\frac{T_{2}-T_{1}}{\frac{x}{k A}}$

DISCUSSION AND RESULT

For the combustion chamber including the insulation material:

$$
\begin{aligned}
& q=\frac{T_{2}-T_{1}}{\frac{x_{1}}{k_{1} A_{1}} \frac{x_{2}}{k_{2} A_{2}}+\frac{x_{3}}{k_{3} A_{3}}} \\
& \frac{x_{2}}{k_{2} A_{2}}=\frac{T_{2}-T_{1}}{q}-\left(\frac{x_{1}}{k_{1} A_{1}}+\frac{x_{3}}{k_{3} A_{3}}\right) \ldots . . . \\
& \text { Since: } x_{1}=x_{3} \text { and } k_{1}=k_{3} \\
& x_{2}=-k_{2} A_{2}\left[\frac{\left(T_{2}-T_{1}\right)}{q}-\frac{2 x_{1}}{k_{1} A_{1}}\right] 17
\end{aligned}
$$

Where: $\mathrm{q}=$ heat power or flux, $\mathrm{J} / \mathrm{m}^{2} \mathrm{~s}, \mathrm{Q}=$ heat transfer rate, $\mathrm{J} / \mathrm{s}, ; \mathrm{x}_{1}=\mathrm{x}_{3}$ thickness of combustion chamber material, $\mathrm{m}, \mathrm{x}_{2}=$ thickness of insulation material ; $\mathrm{k}_{1}=\mathrm{k}_{3}=$ thermal conductivity of combustion chamber material $; \mathrm{k}_{2}=$ thermal conductivity of insulation material.; $\mathrm{T}_{1}=$ initial room temperature of the combustion chamber $\left({ }^{\circ} \mathrm{C}\right) ; \quad \mathrm{T}_{2}=$ burning temperature of combustible material $\left({ }^{\circ} \mathrm{C}\right) ; \mathrm{T}_{3}=$ the inner temperature at the interface of the combustion material and the insulation, $\left({ }^{\circ} \mathrm{C}\right) ; \mathrm{T}=$ the outer temperature at the interface of the insulator and combustion chamber material, $\left({ }^{\circ} \mathrm{C}\right) ; \mathrm{A}_{1}=\mathrm{A}_{2}$ area of combustion chamber, $\mathrm{mm}^{2} ; \mathrm{A}_{2}=$ area of insulation material

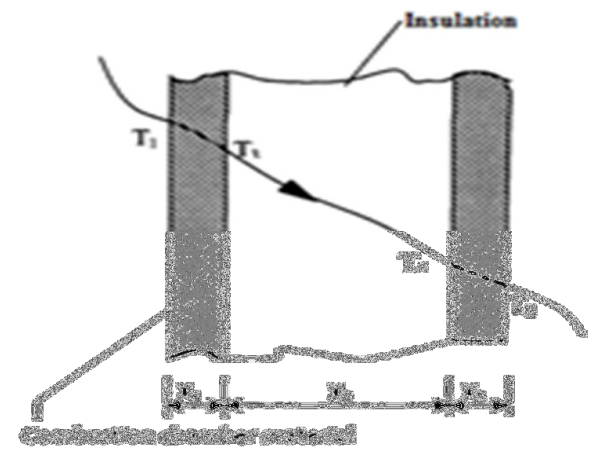

Fig 2: The heat transfer through the wall of the insulated combustion chamber

The burning temperature $\left(\mathrm{T}_{2}\right)$ of the combustible material is taken to be approximately $200^{\circ} \mathrm{Cfrom}$ experiments carried out in the laboratory. The average room temperature $\left(T_{1}\right)$ before combustion was taken to be $25^{\circ} \mathrm{C}$. Table 1 shows the various burning temperatures for some waste materials carried out in the laboratory.

Table 1: Burning Temperature for various wastes

\begin{tabular}{ll}
\hline Waste Material & Burning Temperature in ${ }^{\circ} \mathrm{C}$ \\
\hline Paper & 70 \\
Old Clothing & 100 \\
Saw dust and wood & 140 \\
Chunks of food & 150 \\
Plastic & 160 \\
\hline
\end{tabular}

The combustion chamber material is made up of steel (carbon steel, max $1.5 \%$ carbon) because it is cheap, readily available and has reasonable thermal conductivity (Ibhadode, 2001). This gave us the thickness of the lagging material that was used in the work.

Efficiency of the system:Performance evaluation entailed incineration of typical domestic wastes. Solid wastesused for performance evaluation were collected from Ugbowo and Uselu area in Benin City. $6 \mathrm{~kg}$ of the solid waste comprising mostly of papers, cartons and polyethene sachets commonly used as packaging material in Nigeria was fed into the combustion chamber and ignited.

The waste was allowed to burn completely and escaping flue gases were bubbled through the drum filled with water. At the end of the combustion process, the quantity of waste was reduced. The ashes produced during burning were trapped in the ash tray, and this made the whole process very neat and convenient to the user and the environment.The input of our incinerator was supposed to burn $6 \mathrm{~kg}$ of waste in ten minutes. During first testing it burnt $4 \mathrm{~kg}$ in ten minutes, during the second testing it burnt $4.5 \mathrm{~kg}$ in 
ten minutes and during the third testing it burnt $4.5 \mathrm{~kg}$ in ten minutes.

Table 3: Summary of Results

\begin{tabular}{llllll}
\hline Parameters & $\begin{array}{l}\text { Volume of } \\
\text { fuel used } \\
\text { (waste oil) }\end{array}$ & $\begin{array}{l}\text { Heat } \\
\text { power }\end{array}$ & $\begin{array}{l}\text { Rate of } \\
\text { heat } \\
\text { transfer }\end{array}$ & $\begin{array}{l}\text { Total } \\
\text { thermal } \\
\text { resistance }\end{array}$ & $\begin{array}{l}\text { Thickness } \\
\text { of } \\
\text { lagging } \\
\text { material }\end{array}$ \\
\hline Values & $49.5 \times 10^{6} \mathrm{~mm}^{3}$ & $750 \mathrm{KW}$ & $55350 \mathrm{~J}$ & $1.225 \mathrm{~W} / \mathrm{K}$ & $70 \mathrm{~mm}$ \\
\hline
\end{tabular}

Conclusion: An incinerator has been designed and fabricated to handle domestic solid waste and waste oil generated from local automobile workshops. Thus incineration has been taken a step further by scrubbing the waste gas with water to remove harmful by-products and dust from the exhaust gas. Test results indicated that the system can be used for waste disposal. Since municipal wastes systems are not so close to the people, we forsee a situation where there would be a future legislation to have an incinerator in our homes. The outcome of this work is thus a stepping stone in this direction.

\section{REFERENCES}

Cheremisinoff, PN (1990).Focus on high hazard pollutants, A scientific paper discussing hazardous pollutants, Pollution Engineering vol. 22 (2) P.67-79. .

Hogg P. (2009).Constitutional Authority over Greenhouse Gas Emissions, A question of parliamentary power, Criminal law and control of Greenhouse Gas emissions, C.D. Howe Institute, Backgrounder.
Ibhadode,AO (2001). Introduction to Manufacturing Technology, Ambik Press, Benin City, Edo State, Nigeria

Kassenberg, G; Sutter, RD (2006). Strategic Evaluation on Environment and risk prevention under structural and cohesion funds for the period 2007-2013.National Evaluation Report.

Lienhard, JH (2005). A heat transfer textbook, $3^{\text {rd }}$ Edition,Phlogiston Press, Cambridge Massachusetts.

Perry, RH; Green DW(1984)Perry's Chemical Engineers' Hand book, $6^{\text {th }}$ Edition, p.9-72 Mc Graw Hill Book copy. ISBN 0- 07-049479-7.

Rajput, RK (2004) Heat and Mass Transfer, S.Chad and Company Limited, New Delhi.

Santoteri, JJ (1985).Design and operating problems of hazardous Waste incinerators, Environmental Progress and Sustainable Energy, Vol.4, (4), p. 246-251.

Taylor, FO (2004). Utilization of waste to Energy, The English University Press, Woodruff, TB, Lammers Steam Plant Operation, $8^{\text {th }}$ Edition, McGraw Hill Professional 